\title{
IMPLEMENTASI MAQASHID SYARIAH PADA PETANI DESA TANJUNGSARI KECAMATAN RAJADESA KABUPATEN CIAMIS
}

\author{
Dudi Badruzaman \\ STAI Sabili Bandung \\ badruzaman.dudi@yahoo.com
}

\begin{abstract}
This study aims to answer two questions, namely: How is the Implementation of Maqashid Sharia in the farmers of Tanjungsari village, Rajadesa sub-district, Ciamis district and how is the implementation problem of Maqasid as-Syari'ah in Tanjungsari village, Rajadesa sub-district, Ciamis district. This research is a qualitative research with a case study approach of economic relations, data collection techniques through observation, interviews and documentation. The data that has been collected is analyzed descriptively qualitatively with an inductive pattern. The results showed that, firstly; the implementation of Maqasidd As-Shari'ah is very important for human resources themselves to achieve good socio-economic value for the environment of the tanjungsari village farming community itself. As the purpose of life in each of the five dimensions of Maqasid As-Shari'ah is to preserve and preserve religion, soul, intellect, descent and wealth for the best life in the world and the hereafter. Second; The problem of implementation in each indicator in the five dimensions of Maqasid As-Shari'ah is a sign that the community still does not fully understand the objectives of the Shari'a which must be fulfilled as the basis of the values of welfare and benefit that must be achieved by humans themselves as representatives of Allah SWT in the world by maintaining and preserve nature and its contents with the foundation of indicators in five dimensions in Maqasid AsSyari'ah. So in conclusion, the implementation of Maqasid AsShari'ah in the tanjungsari village peasant community became a 'scourge' in developing and creating a good atmosphere of community life in creating benefit for humanity themselves in the world and in the hereafter.
\end{abstract}

Keywords: Keywords: Islam, Human, Maqashid as-syariah. 


\section{PENDAHULUAN}

Pada hakekatnya, ekonomi menjadi hal yang sangat esensi di setiap kehidupan masyarakat. Terutama dalam Islam, Ekonomi Islam sendiri merupakan ajaran yang bersifat Syumuliyah, yaitu mencangkum seluruh aspek kehidupan. Ekonomi Islam kini sudah menjadi trending dalam dunia perekonomian di wilayah lokal ataupun internasional. Ekonomi syariah atau ekonomi Islam sendiri menurut sejarahnya sudah mengakar di dunia keIslam-an sejak turunnya Wahyu kepada Nabi Muhammad saw bahkan di dalam sebuah buku yang berjudul Reading In Islamic Economic Thought karya Abdul Hasan Sadeq dan Ghazali tahun 1992 menyebutkan bahwa umur dari ekonomi Islam/syariah sesungguhnya sama tuanya dengan peradaban Islam itu sendiri. Kesadaran ini sudah membangkitkan umat Islam sendiri dalam menerapkan prinsip-prinsip ekonomi Islam dalam setiap aktifitas ekonomi mereka, entah dalam perbankan atau aktivitas keuangan lainnya. Dengan pertumbuhan yang pesat ini, pasar Ekonomi Syariah menjadi potensi yang kuat selain dalam mensejahterakan umat juga sebagai dakwah dalam memajukan perkembangan agama Islam di zaman yang cepat berubah ini. ${ }^{1}$

Menurut The Pew Forum on religion \& publi life tahun 2010, menyajikan data yang menunjukkan bahwa jumlah penduduk Indonesia merupakan jumlah terbanyak. Oleh karena itu, dari kedua problem tersebut, dibutuhkan metode pendekatan 'Islamisasi Ilmu Ekonomi' yaitu dengan melalui pendekatan Integratif. Yaitu memosisikan ilmu ekonomi konvensional sebagai benchmark lalu dimodifikasi kemudian di-insersi nilainilai Islam di dalamnya sehingga bisa melahirkan ilmu ekonomi Islam yang memiliki perbedaan secara filosofis dan praktis.

Tujuan dari pembangunan ekonomi tersebut memiliki dasar bahwa ekonomi dalam Islam bukan hanya menitik beratkan kepada pembangunan pertumbuhan ekonomi secara global ataupun umum saja, akan tetapi pembangunan ekonomi menurut Islam juga menitik beratkan kepada kualitas manusia di dalamnya terkhusus kepada umat Muslim sendiri. Sebagaimana Islam sendiri adalah agama yang memang di utus untuk memperbaiki Akhlak yang dengan akhlak tersebut menunjukkan bahwa kualitas manusia untuk peradaban harus menjadi contoh yang lebih baik dari yang lain untuk kebaikan bersama.

\footnotetext{
1 Irfan Syauqi Beik, "Islamisasi Ilmu Ekonomi”, dalam Jurnal Islamiconomic: Jurnal Ekonomi Islam, (Volume 7 No. 2, 2016), hlm.184.
}

..::: Malia: Jurnal Ekonomi Islam, Volume 11 Nomor 1 Desember 2019 :::.. 
Salah satu daerah yang memiliki potensi swasembadaya pangan besar adalah pulau jawa yang memang secara statistik, Pulau Jawa memiliki jumlah tinggi dalam kontribusinya meningkatkan potensi yang tinggi terhadap ketahanan pangan daerah maupun nasional. Terutama Jawa Barat, seperti yang di gambarkan pada data di bawah ini. Padi menjadi elemen pertanian yang kuat sebagai produsen pertanian yang ada di Indonesia.

Akan tetapi angka dari BPS menunjukkan bahwa Provinsi Jawa Barat menjadi lumbung pangan terbesar dari pada provinsi lainnya di setiap daerah. Bukan hanya padi, akan tetapi komoditi lainnya memiliki nilai penduduk muslim terbesar pertama di dunia setelah India dan Pakistan. Nilai tersebut berjumlah $12,7 \%$ dari penduduk bumi. Jumlah tersebut menjadi potensi besar bagi nilai pembangunan dan pertumbuhan ekonomi Indonesia. tinggi dari pada daerah lain. Dalam kontribusinya pun terhadap pangan nasional serta nilai ekspor sangat tinggi. ${ }^{2}$ Maka dari itu, Jawa Barat menjadi penyumbang jumlah komoditas pertanian terbesar kedua tingkat nasional. Hal tersebut memang terjadi karena lahan yang dimiliki daerah Jawa Barat memiliki nilai lahan 34.062 yang mana terbagi menjadi dua 2.226 lahan Non irigasi dan 31.836 lahan irigasi. ${ }^{3}$ Kontribusi besar tersebut tidak lain memang di dukung dari mayoritas mata pencaharian penduduk masyarakat Ciamis adalah bertani lalu di ikuti oleh pedagang. Sub daerah yang memiliki potensi tersebut di kabupaten Ciamis adalah kecamatan Rajadesa.

Kecamatan Rajadesa yang memiliki luas 39,61 Km2 dengan luas panen 3440 ini memiliki potensi pertanian yang lumayan besar. Disertai mayoritas pekerjaan yang dilakukan oleh masyarakat kecamatan Rajadesa adalah bertani, berdagang, dan di ikuti oleh perantauan ke kota/urbanisasi.

Kecamatan Rajadesa sendiri memiliki tujuh desa yang mana diantara tujuh desa ini desa Tanjungsari adalah desa yang memiliki luas lahan yang paling lebar dari pada desa yang lain serta jumlah penduduk yang lebih banyak dari pada jumlah penduduk desa yang lain. Penduduk desa Rajadesa juga 100\% beragama Islam. Oleh karena itu, dari dasar dan sumber yang ada. Sistem pembangunan ekonomi terkhusus pada aspek pertanian di desa ini harus lebih ditekankan dan di perjelas akan kualitas pembangunan

\footnotetext{
${ }^{2}$ Wijayanto, Ekspor Komoditas Pertanian Jatim Peringkat Dua Nasional, di akses di https://radarsurabaya.jawapos.com/ pada tanggal 19-06-2019

3 BPS JATIM, "Luas Lahan Sawah Menurut Kabupaten/Kota dan Jenis Pengairan di Provinsi Jawaimur 2016”, 'https://jatim.bps.go.id/ , Di akses pada tanggal 15 Januari 2019, Jam 21.25 WIB
} 
manusianya. Terkhusus dalam pandangan Islam sendiri, yang mana dari aspek pembangunan, Islam sendiri memiliki konsep kemaslahatan yang terperinci dari sebagian ulama klasik ataupun kontemporer bahwa kemaslahatan adalah aspek yang harus manusia capai untuk menjadikan kehidupan yang sejahtera di-dunia dan di-akhirat, sesuai dengan perintah Allah SWT di Al Quran dan As Sunnah. ${ }^{4}$

Kesejahteraan yang menjadi nilai dari tercapainya aspek-aspek perintah beserta larangan Allah SWT di dalam Al Quran beserta di As Sunnah, beberapa ulama kontemporer menjabarkan beberapa indikator utama dalam pemenuhan prinsip hidup manusia di dunia antara lain; Agama (Ad din), jiwa (An Nafs), akal (Al Aql), keturunan (An Nasl) dan harta (Al Mal) inilah bentuk dari prinsip Maqasid as-Syari'ah. ${ }^{5}$ Menurut Imam al Ghazali dalam kitabnya Ihya Ulumuddin menjelaskan bahwa; tujuan dari syariat sendiri memiliki beberapa kriteria antara lain; kesejahteraan manusia, yang terletak pada perlindungan agama atau keimanan, jiwa, akal, keturunan dan kekayaan. ${ }^{6}$

Hal demikian juga di paparkan oleh salah satu ulama besar AsySyathibi menyatakan bahwa kegiatan ekonomi dikatakan mencapai tujuannya mencapai aspek lima perlindungan dalam syariat, yaitu menjaga agama (hifdzu ad din), menjaga jiwa (hidfzu an nafs), menjaga akal (hifdzu al aql), menjaga keturunan (hifdzu an nasl) dan menjaga harta (hifdzu al mal).

\section{KAJIAN TEORI}

Demikian indikator di atas hingga kini masih di gunakan oleh beberapa lembaga survei atau personal dalam mengukur tingkat kesejahteraan manusia (IPM) versi Islam. Sehingga dalam penelitian ini perlunya peneliti menggunakan indikator, teori dan objek penelitian di desa Tanjungsari karena potensi dan ruang yang sangat kuat akan indeks pembangunan manusianya, terkhusus kepada para petani yang $100 \%$ adalah penduduk beragama Islam sehingga analisa penelitian dalam judul Implementasi Maqashid Syariah pada Masyarakat Petani Desa Tanjungsari

\footnotetext{
4 Irfan Syauqi Beik dan Laily Dwi Arsyianti, 'Ekonomi Pembangunan Syariah', (Jakarta: Rajawali Pers, 2016), hlm. 17

5 Muslimin Kara, 'Pemikiran Al-Syatibi tentang Maslahah dan Implementasinya dalam pengembangan Ekonomi Syariah', (ASSETS, Volume 2, Nomor 2, 2012) hlm.173-184

6 Agus Waluyo, Ekonomi Islam dalam bingkai Maqashid Asy-Syariah, (Yogyakarta, Ekuilibria, 2018) hlm.80
} 
Kecamatan Rajadesa Kabupaten Ciamis ini sudah sesuai dengan kaidahnya atau belum.

\section{METODOLOGI}

\section{Jenis penelitian}

Riset ilmu ekonomi akan memiliki kedalaman akar Ontology, kekukuhan batang dahan ranting Epistimology serta kelebatan daun dan buah Axiology jikalau berada di dalam satu keselarasan filosofi ilmu yang baik dan benar. ${ }^{7}$ Penelitian ini adalah penelitian kualitatif. Yang mana, penelitian ini menunju pada penyelidikan tentang kehidupan ekonomi (masyarakat, perusahaan, negara dan lain sebagainya), sejarah perkembangan maupun kemunduran ekonomi, berbagai tindakan seseorang pelaku ekonomi ataupun kebijakan entitas bisnis.

Di pengertian yang lain dengan maksud yang sama, penelitian kualitatif adalah penelitian yang berdasarkan latar alamiah yang menghasilkan suatu hasil secara alamiah tanpa adanya campur tangan manusia. Hasil penelitian ini adalah tampilan yang berupa kata-kata lisan atau tertulis yang dicermati peneliti serta benda-benda yang diamati sampai mendetail. ${ }^{8}$

Penelitian ilmu ekonomi Islam ini, yaitu tentang pencapaian pembangunan manusia Human Development yang memang berdasarkan keadaan ilmiah dari suatu hasil penyelidikan terhadap suatu kondisi. Pendekatan yang digunakan di dalam penelitian ini melalui studi kasus dari implementasi hidup para petani dengan sistematika Islamic Human Development indikator di desa Tanjungsari.

\section{Tehnik Pengumpulan Data}

Teknik pengumpulan data pada penelitian ini antara lain;

a. Observasi, dengan melakukan pengamatan langsung masyarakat di desa Tanjungsari entah mereka yang bekerja sebagai petani, pemilik lahan dan tokoh-tokoh masyarakat lainnya.

b. Wawancara, proses interaksi peneliti dengan pihak-pihak terkait yang memiliki peran dalam tujuan penelitian ini, di antaranya; 1) tokohtokoh Masyarakat desa Tanjungsari, 2) pejabat publik desa

\footnotetext{
${ }^{7}$ Sonny Leksono, 'Penelitian Kualitatif Ilmu Ekonomi dari Metodologi ke Metode', (Jakarta: Raja Grafindo Persada, 2013), hlm.18.

8 Suharsimi Arikunto, 'Prosedur Penelitian; Suatu Pendekatan Praktik', (Jakarta: Rhineka Cipta, 2010), hlm.3.
} 
Tanjungsari, 3) petani (pemilik dan pengelola lahan) desa Tanjungsari, 4) masyarakat sekitar desa Tanjungsari yang tidak memiliki kriteria sebelumnya.

c. Dokumentasi, mengumpulkan data yang memiliki relevansi terhadap tema penelitian dengan berbagai bentuk seperti dokumen, jurnal, maupun laporan, seperti; 1) Data Indeks pembangunan manusia di cimais, 2) data luas persawahan dan hasil produksi swasemba daya pangan di kecamatan rajadesa, dan 3) literatur lainnya yang relevan dengan topik penelitian.

Metode penelitian ini menggunakan metode penelitian kualitatif. Metode ini dilakukan dengan cara membaca data, membandingkan dan menganalisis sesuai dengan metodologi dan teori yaitu Maqasid assyari'ah sehingga menemukan kesimpulan yang sesuai. Hasil analisis ini berupa penjabaran yang bersifat rekomendasi.

\section{PEMBAHASAN}

Maqasid as-syari'ah ialah sebuah nama atau laqab yang terdiri dari dua lafaz, yaitu Maqasid dan Syari'ah. Maqasid merupakan bentuk jamak dari kata Maqsud. Akar kata berasal dari fi'il tsulathi yang artinya tujuan, maksud, objektif, prinsip, niat, dan sasaran. ${ }^{9}$ Sedangkan Syari'ah berasal dari kata Syara'a berarti 'jalan menuju sumber mata air'. Menurut As-Syatibi Syariah berarti seluruh aturan agama yang mengatur tentang tingkah laku, ucapan dan kepercayaan manusia.

Al-Qardawi mengatakan bahwa Maqasid as- syari'ah adalah tujuan yang menjadi target teks pada hukum-hukum partikular untuk direalisasikan kedalam bentuk kehidupan manusia. Baik berupa perintah, larangan, dan mubah, untuk individu, keluarga, jamaah, dan umat. Islam memiliki sistem ekonomi fundamental yang berbeda dengan sistem ekonomi konvensional sekarang ini, sistem ekonomi syariah, mengacu pada akar dalam syariat yaitu Maqasid as- syari'ah dengan mendasar pada konsep-konsep Islam tentang kebahagiaan manusia (Fallah) dan kehidupan yang baik (Hayatan Thayyibah) yang menekankan pada aspek persaudaraan (Ukhuwah), keadilan Sosioekonomi, dan pemenuhan kebutuhan-kebutuhan spiritual manusia. Perkembangan ekonomi Islam harus berbasis kepada padangan keagamaan

\footnotetext{
9 Agus Waluyo, 'Ekonomi Islam dalam Bingkai Maqashid Asy-Syari'ah', (Yogyakarta, Ekuilibria, 2018), hlm.16
} 
yaitu kepada Islam itu sendiri. Sehingga dalam hal ini, beberapa ulama merumuskan objek dari Syari'ah (Maqasid as- syari'ah) sebagai nilai atau indikator dari kesejahteraan manusia dan seluruh makhluk hidup.

Tingkat kemaslahatan dari penyempurnaan syariat ini dikategorikan menjadi 3 indikator tingkat dari segi substansinya antara lain:

1. Maslahat level ad-Daruriyah

Kebutuhan ad-Daruriyah (Primer) ini adalah kebutuhan yang berada di level tertinggi dari tiga level lainnya, yaitu segala hal yang menjadi dasar eksistensi kehidupan manusia yang harus dipenuhi demi keberlanjutan hidup mereka. Hal ini dapat disimpulkan kepada lima sendi utama yaitu, agama, jiwa, akal, keturunan, dan harta. Bila sendi ini tidak terpelihara dengan baik, maka kehidupan manusia akan kacau, kemaslahatan tidak akan terwujud, baik di dunia maupun di akhirat. Dari pemeliharaan kelima dasar dari Maqasid as- syari'ah menjadi prioritas menurut urutannya, yang pertama adalah ad-Din yang menjadi skala prioritas yang utama dari pada yang kedua yaitu an-Nafs, dan prioritas kedua an-Nafs menjadi hal yang utama sebelum sendi yang ketiga, dan begitu seterusnya.

2. Maslahat level al-hajiyat

Maslahat pada level ini adalah kebutuhan pada level hajiyat (sekunder) yaitu sesuatu yang dibutuhkan oleh manusia untuk menghilangkan kesulitan dan menolak setiap halangan. Yang mana, ketiadaan aspek ini tidak sampai mengancam kehidupan manusia menjadi rusak, melainkan hanya sekedar menimbulkan kesulitan dan kesusahan. Prinsip yang digunakan oleh kebutuhan di level kedua ini adalah prinsip yang menghilangkan, kerugian, kehilangan dan meringankan beban manusia, dan memudahkan urusan manusia. Dalam hal ini Islam menitik beratkan kepada bidang Muamalah dan Uqubat (Pidana).

3. Maslahat level tahsiniyat

Maslahah level ketiga adalah tingkat kebutuhan tahsiniyah, yaitu tindakan atau perilaku yang pada intinya berhubungan dengan akhlak atau tingkah laku/sikap yang baik, serta pemeliharaan tindakan utama dalam bidang ibadah, adat dan muamalah. Artinya, jika aspek ini tidak terwujud, maka kehidupan manusia tidak akan terancam dalam kekacauan, seperti kalau tidak terwujud aspek daruriyat dan juga tidak membawa kesusahan seperti tidak terpenuhinya aspek hajiyat. Namun, tidak adanya aspek $\operatorname{tah}\{$ siniyat ini akan menimbulkan suatu kondisi yang 
kurang harmonis dalam pandangan adat kebiasaan, menyalahi kepatuhan, dan menurunkan martabat pribadi ataupun masyarakat.

Pada pernyataan Imam Al-Ghazali dalam kitab al-Musytasyfa, menyebutkan bahwa iman menjadi tonggak utama dan yang pertama dalam daftar Maqasid as-syari'ah. Iman menjadi fondasi awal hubungan-hubungan kemanusiaan satu sama lain dalam suatu pergaulan dalam mencapai kebahagiaan bersama. Selain itu alasan Imam Al- Ghazali menyebut iman pertama kali dalam deretan Maqasid as-syari'ah ialah menjadi suatu penyaring moral bagi alokasi dan distribusi sumber daya atas dasar keadilan sosial-ekonomi. Pendapat tersebut selaras dengan Mabda' Maqasid assyari'ah dalam perspektif tradisional.

Di dalam peletakan prioritas urutan dalam Maqasid as-Syari'ah ini memiliki beberapa perbedaan urutan dalam beberapa karya as-Shatibi, akan tetapi imam As-Shatibi selalu mengedepankan agama (Ad-Din) dan jiwa (AnNafs) terlebih dahulu. Sebagaimana di jelaskan oleh Al-Ghazali di atas, menjaga manusia dari sesuatu yang buruk. selain itu, tujuan dari syariat sendiri adalah menciptakan dan meningkatkan kesejahteraan manusia yang terpusat pada perlindungan agama, jiwa, akal, keturunan dan harta. Kelima dimensi di atas menjadi kebutuhan dasar dan fondasi dari perkembangan manusia perspektif Islam. Menurut MB Hendrie Anto, kelima dimensi tersebut dapat mengukur dua bentuk kesejahteraan manusia; 1) kesejahteraan materi (Material Welfare) dan Kesejahteraan Non-Materi (Non-Material Welfare), yang mana dari kedua bentuk kesejahteraan ini memiliki keterkaitan yang terikat dengan indikator harta $(a l-M a l)$ yaitu Material Welfare. Karena dalam Islam menekankan pokok kepemilikan harta beserta distribusinya terhadap masyarakat sekitar sebagai bentuk pencapaian Maslahah kemudian Fala. Tentang pentingnya agama atau keimanan di dalam Al-Qur'an, Allah SWT sudah melarang bahwa seorang muslim khususnya tidak boleh murtad (keluar dari agamanya).

\section{ANALISIS IMPLEMENTASI MAQASID ASYARI'AH PADA PETANI DESA TANJUNGSARI KECAMATAN RAJADE KABUPATEN CIAMIS}

Meninjau lapangan dari penerapan Maqasid As-Syari'ah pada masyarakat petani desa tanjungsari adalah suatu bentuk dari penilaian sejauh mana peningkatan atau bahkan penurunan tingkat religiositas petani desa 
tanjungsari dilihat dari lima dimensi dari Maqasid As-Syari'ah ; yaitu ad Din, an Nafs, an Nasl, an 'Aql dan al Mal.

Kelima dimensi tersebut menjadi patokan dalam penilaian tingkah laku masyarakat muslim di desa tanjungsari yang mayoritas penduduknya bekerja sebagai petani dan buruh tani. Antara lain untuk (1) memelihara agama (hifz al din), (2) jiwa (hizf al nafs), (3) akal pikiran (hifz al 'aql), (4) keturunan (hifz al nasl), dan (5) harta kekayaan (hifz al mal).

hifz al din; ditunjukan dari dua indikator utama yaitu indikator positif dan indikator negatif. Indikator positif melihat dampak dan manfaat dari pemeliharaan agama sendiri yaitu terbagi menjadi 5 dimensi antara lain; jumlah masjid; yang memiliki manfaat tersendiri bagi suatu lingkungan atau wilayah dalam memenuhi kebutuhan ibadah masyarakat terkhusus kepada petani desa tanjungsari sendiri.

Karena jika di suatu lingkungan muslim tidak ada masjid, maka tentu pemeliharaan agama disini tidak ada. Sebagaimana kita mengetahui bahwa masjid menjadi fondasi utama masyarakat muslim dalam melaksanakan ibadah wajib maupun Sunnah. Puasa dan zakat adalah salah dua dari instrumen rukun Islam yang wajib di tunaikan oleh seluruh umat muslim, tak terkecuali yang seorang mukallaf. Masyarakat petani desa Selomukti menunjukkan ketaatan dari pelaksanaan ibadah puasa dan zakat ini setiap tahunnya. Bahkan melebihi dari itu, masyarakat petani desa Selomukti memiliki nilai budaya sosial yang tinggi antar tetangga dan orang-orang di sekitarnya.

Jika dari dimensi ini tidak di tunaikan, maka salah satu bentuk eksistensi dan pemeliharaan agama tidak ada sehingga hal demikian bisa disebut sebagai perbuatan tercela yang melawan ketentuan syariah. Selanjutnya adalah jumlah ulama yang meskipun bukan kewajiban dari Islam. Akan tetapi tentu kebutuhan masyarakat akan ilmu agama dan tokoh dalam menyelesaikan berbagai masalah pribadi dan umum, ulama memiliki peran penting sebagai bentuk jalan dakwah dari agama kepada khalayak masyarakat. Sehingga masyarakat pun bisa tetap memiliki panutan. Sebagaimana sabda Nabi SAW. Bahwasanya, ulama adalah warisan para nabi. Meski di desa tanjungsari tidak memiliki ulama dalam tingkatan yang tinggi sebagaimana kriteria sebenarnya, akan tetapi wakil dari ulama sudah di wakili oleh tokoh-tokoh agama yang aktif dalam mengayomi masyarakat petani desa tanjungsari. 
Partisipasi sekolah agama dan realisasi dana amal menjadi acuan juga dalam meningkatkan pemeliharaan agama di suatu lingkungan masyarakat. Pendidikan menjadi salah satu aspek yang diwajibkan oleh Rasulullah Saw untuk umatnya dari buaian hingga liang kubur, termasuk pendidikan agama yang tentunya selain berisi khazanah keilmuan dan ajaran agama, pendidikan agama juga menjadi dasar penerapan budaya dan implementasi adab dan akhlak bagi manusia.

Realisasi dana amal juga penting dalam memakmurkan masyarakat desa tanjungsari, hal tersebut ter-record setiap ada kegiatan gotong royong remaja masjid dan setiap idul fitri dan Idul Adha yang mana realisasi dana diberikan kepada pengurus masjid dan digunakan untuk memakmurkan masjid. Realisasi amal juga dalam memelihara agama, sebagaimana tugas manusia yang memiliki kemampuan ekonomi yang baik di tuntut untuk menyedekahkan sekian persen harta yang mereka miliki kepada orang yang tidak mampu karena dari agama sendiri mengajarkan sebagian harta manusia adalah hak dari yang lain juga.

Sedangkan dari indikator yang negatif pemeliharaan agama antara lain; angka kriminalitas dan indeks persepsi korupsi. Kedua indikator tersebut menjadi bentuk dari menghilangkan mafsadat (kerusakan) sosial masyarakat. Karena jika dari kedua indikator ini banyak masyarakat yang melanggarnya maka eksistensi agama beserta budaya adab dan akhlaknya juga akan rusak. Tak terkecuali dampak nyata seperti kerusuhan, ketidaknyamanan, rasa tidak tenang dalam beribadah dan bekerja, dan dampak ekonomi yang akan membuat sebagian masyarakat dirugikan dan sengsara.

Yang kedua adalah dimensi pemeliharaan jiwa (hifdzu an-nafs) yang mana mencakup beberapa indikator, antara lain; angka harapan hidup; di maksud untuk menjamin eksistensi penganut agama Islam sendiri dalam menempuh kehidupan yang lebih lama yang mana menandakan bahwa semakin tinggi tingkat harapan hidup seseorang maka dia akan tetap produktif dengan nilai kehidupan yang lebih baik.

Yang kedua adalah morbiditas yang menjadi bagian dari pemeliharaan manusia karena jika semakin tinggi morbiditas seseorang maka tingkat efektivitas dan produktivitas manusia akan semakin menurun, begitupun kepada tingkat pelaksanaan ibadah dalam kesehariannya. Jika tingkat morbiditas semakin tinggi, maka tingkat ibadah pun akan terganggu. Meskipun itu, masyarakat petani desa tanjungsari sudah memiliki penurunan tingkat morbiditas di beberapa penyakit musiman sebagai petani. 
Hal tersebut di sebabkan dari tingkat kesadaran akan pola hidup dan pekerjaan yang harus di jaga oleh masyarakat petani. Dari indikator kesehatan terdapat tiga indikator utama dalam pemeliharaan jiwa (an-Nafs); yang pertama adalah, kunjungan fasilitas kesehatan menjadi salah satu faktor tingkat kesehatan masyarakat petani, semakin tinggi tingkat kunjungan bukan berarti semakin tinggi juga morbiditas masyarakat, akan tetapi jumlah kunjungan menjadi acuan dari kepedulian masyarakat akan kesehatan yang mereka miliki. Karena mau bagaimanapun setiap orang tidak akan selalu sehat selamanya, meskipun ada yang datang ke puskesmas setempat akan selalu di dukung oleh fasilitas kesehatan yang memadai seperti jumlah pengurus puskesmas yang harus sesuai dengan rasio jumlah masyarakat se kecamatan dan setiap desa masing-masing.

Selain itu tingkat kepedulian masyarakat akan imunisasi juga harus di perhatikan karena sebagaimana fungsi imunisasi sendiri agar generasi aman dari segala penyakit rentan yang sudah bisa tersebar dari siapapun dan dimanapun. Semua aspek kesehatan tersebut bukan tidak lain mengacu pada pemeliharaan manusia atau jiwa setiap masyarakat petani terkhusus desa tanjungsari kecamatan Rajadesa sendiri. Sedangkan dari aspek indikator negatif antara lain; pelanggaran obat-obatan dan penanggulangan rokok, kedua indikator ini menjadi salah satu pertimbangan juga dalam menjaga dan memelihara jiwa (an-Nafs) karena keduanya termasuk hal yang perlu di hindari oleh setiap orang agar terciptanya kondisi badan yang sehat luar dalam sehingga dalam beribadah pun bisa lancar. Sayangnya, masyarakat petani desa tanjungsari sebagian komoditi pertaniannya adalah tembakau, yang mana mayoritas masyarakat Rajadesa menjadi konsumen sendiri produk yang mereka tanam. Meskipun dalam kasusnya tidak ada penduduk yang terkena penyakit akut karena rokok, akan tetapi aspek tersebut juga perlu di perhatikan pemakaian dan penggunaannya.

Dimensi yang ketiga adalah pemeliharaan intelektual ( $a l$-'Aql), dimensi ini meliputi beberapa indikator yang mencakup keseluruhan tentang menjaga akal atau intelektual. Sebagaimana pesan Al-Quran dan Hadith banyak mengutip dengan mewajibkan setiap umat muslim untuk mencari ilmu dan menggunakannya dengan sebaik-baiknya manfaat bagi masyarakat sekitar. Dari dimensi al-'Aql ini terbagi menjadi sembilan indikator yang mana setiap indikator tersebut memiliki acuan nilai tingkat yang tinggi. Semakin tinggi nilai dan pertumbuhan di setiap indikator al-'Aql, maka 
semakin tinggi implementasi dimensi $A l$-'Aql sehingga eksistensi pemeliharaan intelektual atau akal ini tinggi dan baik.

Diantara indikatornya adalah angka partisipasi sekolah, rata-rata lama sekolah, jumlah lembaga pendidikan, tenaga pengajar, akses internet, angka melek huruf, angka buta huruf, jumlah hak paten dan pengeluaran pendidikan rumah tangga. Dari indikator-indikator di atas ada beberapa indikator yang memang memiliki acuan nilai yang rendah sebagai tanda semakin baiknya pemeliharaan dimensi Al-'Aql ini seperti angka buta huruf yang menggambarkan bahwa semakin sedikit angka buta huruf disini , maka masyarakat dinilai semakin tinggi pengimplementasian maqashid as-syariah ini di lingkungannya.

Sedangkan pengeluaran pendidikan rumah tangga adalah suatu acuan bahwa semakin cakap suatu keluarga dalam memenuhi kebutuhan pendidikan anak didiknya maka semakin tinggi implementasi pendidikan di keluarga tersebut. Sehingga dari semua indikator $A l$ - $A q l$ di atas menjadi patokan bahwa suatu masyarakat terkhusus masyarakat petani desa Selomukti memiliki nilai pendidikan yang baik dan penerapannya dalam sosial menjadi acuan bahwa semakin tinggi pendidikan dan ilmu yang mereka miliki maka akan semakin baik peradaban dan lingkungan di sekitar mereka.

Dimensi yang ke empat adalah memelihara keturunan (an-Nasl) yang mana dari dimensi ini bertujuan untuk memelihara keturunan atau generasi sehingga aspek implementasi dari maqashid as-syariah adalah keturunan dalam meneruskan tugas manusia di muka bumi serta perintah Allah SWT dan Nabi Muhammad SAW kepada manusia agar memiliki keturunan melalui sebuah pernikahan yang sah secara agama dan konstitusi. Dari dimensi ini, terbagi menjadi dua indikator utama yaitu indikator positif dan negati,

Indikator positif memiliki cabang antara lain; angka reproduksi kasar, rata-rata jumlah kelahiran, angka kelahiran total dan anak lahir hidup. Sedangkan indikator negatif antara lain; tingkat perceraian, angka kematian bayi, angka kematian ibu, angka kematian anak, dan angka kematian balita. Indikator-indikator ini dapat menunjukkan rasio yang seharusnya bisa membandingkan antara indikator positif dan indikator negatif, yang mana penjabaran dalam indikator positif, jika lebih dominan indikator positif dari pada indikator negatif maka kualitas dan pemeliharaan dimensi dari An-Nasl tergolong baik. sebagaimana dalam penjabaran bahwa aspek dimensi an-Nasl adalah untuk menunjukkan bahwa masyarakat petani desa tanjungsari 
memiliki kualitas sosial dan kehidupan yang baik dalam ruang lingkup keluarga dan masyarakat. Meskipun dari beberapa kasus di temukan tidak sedikit yang masih memiliki tingkat kehidupan yang belum mencukupi karena faktor pendidikan dan ekonomi.

Di dalam dimensi an-Nasl memiliki dampak dan manfaat kebaikan yang berjangka panjang. Karena di dalam di setiap indikator dari dimensi anNasl memiliki pengaruh kepada kualitas kesejahteraan keluarga yang mana terfokus kepada hal keturunan dan tingkat keluarga yang harmonis. sedangkan dari pencegahannya; yaitu indikator negatif menghindari kepada hal permasalahan keluarga dan keturunan.

Dimensi yang terakhir adalah dimensi al-Mal yang meliputi tiga indikator besar antara lain; 1) kepemilikan harta, 2) pertumbuhan harta, dan 3) distribusi harta. Dari ketiga indikator tersebut terdapat beberapa bagian antara lain pada indikator kepemilikan harta terdapat dua sub-indikator antara lain; pendapatan perkapita dan rata-rata pendapatan per kapita yang mana memiliki tujuan dan manfaat atas hasil usaha dan pekerjaan yang telah di lakukan oleh mayoritas masyarakat petani desa Selomukti yang nantinya kedua sub-indikator membantu masyarakat sendiri dalam memenuhi kebutuhan hidupnya entah pemenuhan kebutuhan dharuriyah, hajiyat dan tahsiniyat. Untuk sub-indikator yang kedua antara lain; pertumbuhan ekonomi dan pertumbuhan penduduk yang dimaksud disini adalah keseimbangan antara peningkatan daya beli masyarakat dengan jumlah masyarakat yang ada di desa tanjungsari.

Sebagaimana demografi letak desa yang dekat dengan perairan laut dna pegunungan membuat kebutuhan daya beli dan produksi kebutuhan untuk seluruh masyarakat seimbang bahkan bisa memberikan pasokan komoditi kepada beberapa daerah lainnya. Hal tersebut secara nyata adalah bentuk nilai dari keseimbangan sumber daya alam dengan kebutuhan manusia dalam menjalani kehidupan. Jika daya beli masyarakat terlalu banyak maka secara agama sudah melarangnya, begitupun sebaliknya, jika sumber daya alam di kelola dengan baik sehingga mengakibatkan masyarakat kekurangan komoditas kebutuhan, tentu akan membuat dampak yang dapat menyengsarakan masyarakat. Kedua sub-indikator tersebut harus seimbang agar porsi kebutuhan tercukupi dan alam tetap bisa di kelola dalam jangka panjang nanti.

Dan yang terakhir dari sub-indikator distribusi harta antara lain; rasio gini, garis kemiskinan, indeks kemiskinan manusia, persentase penduduk 
miskin, indeks kedalaman kemiskinan, dan indeks keparahan kemiskinan adalah bentuk dari manfaat dan dampak pemerataan harta kekayaan kepada mereka yang membutuhkan. Jika dalam indikator distribusi kepemilikan harta ini di setiap sub-indikatornya masih tergolong memiliki nilai yang tinggi, maka distribusi kekayaan dari masyarakat yang memiliki ekonomi lebih baik serta pemerataan perekonomian oleh pemangku kebijakan setempat kurang begitu baik. Sehingga tentunya dari sub-sub indikator al-mal ini menjadi bagian dari pemerataan kualitas hidup manusia yang lebih layak. Penduduk desa tanjungsari dalam hasil wawancara dengan kepala camat dan sekretaris desa, menyebutkan bahwa tingkat perekonomian masing-masing dusun di seluruh desa tergolong merata. Meskipun ada beberapa kepada keluarga yang masih membutuhkan bantuan ekonomi dari tetangga sekitar bahkan dari pemerintahan setempat.

Macam-macam dampak dan manfaat dari dimensi al-mal di atas menunjukkan manfaat dan dampak yang akan membuat manusia terkhusus masyarakat petani desa rajadesa mampu dan cakap dalam memenuhi kebutuhan mereka tentunya agar setiap kebutuhan, hak dan kewajiban mereka untuk dunia dan akhirat bisa terpenuhi dengan baik dan merata.

\section{ANALISIS BENTUK-BENTUK PERMASALAHAN IMPLEMENTASI MAQASID ASYARI'AH PADA PETANI DESA TANJUNGSARI KECAMATAN RAAJADE KABUPATEN CIAMIS}

Dari kelima dimensi dan di setiap indikator Maqasid As-Syari'ah bukan tidak mungkin tidak akan ada hambatan bagi implementasi Maqasid As-Syari'ah pada masyarakat petani desa rajadesa. Dari setiap dimensi memiliki permasalahan yang beragam dari setiap indikator, antara lain; Dimensi pemeliharaan agama (hifdzu ad-Din) yang terbagi menjadi dua indikator utama; positif dan negatif. Yang mana indikator positif memiliki permasalahan implementasi dari aspek kesungguh-sungguhan dan kesadaran masyarakat sendiri dalam meningkatkan serta ikut serta dalam pelaksanaan secara umum ataupun pribadi dalam ibadah sholat, zakat, puasa.

Hal demikian terjadi karena masyarakat petani desa Selomukti lebih memilih fokus dalam menyelesaikan pekerjaan terlebih dahulu dari pada menuaikan ibadah (dalam hal ini shalat) di waktu awal, serta minimnya generasi yang menempuh pendidikan agama yang lebih tinggi sehingga kader ulama/tokoh agama di suatu daerah terkhusus desa rajadesa tergolong belum memiliki regenerasi ulama/tokoh ulama yang lebih mumpuni dan siap dengan 
kondisi sosial masyarakat desa sendiri. Sedangkan dari indikator negatif adalah permasalahan yang bersumber dari kesadaran pribadi manusia sendiri dalam menjaga ketenteraman dan kesejahteraan lingkungan masyarakat desa dari sikap premanisme, koruptif, kolusi dan nepotisme.

Pada permasalahan implementasi pada dimensi kedua yaitu pemeliharaan jiwa (an-Nasl) adalah tingkat kepedulian masyarakat terkhusus penduduk petani desa rajadesa akan kesehatannya dalam pencegahan dan penanggulangan setiap masalah kesehatan. Meskipun dari pihak UPTD kesehatan setempat sudah melaksanakan sosialisasi kesehatan antar desa demi tercapainya tingkat kesadaran kesehatan yang baik di kalangan masyarakat petani. Sedangkan untuk permasalahan implementasi pada dimensi al-'Aql adalah pola pikir masyarakat yang notabene berada di wilayah pinggir pantai dan pegunungan memiliki tingkat pola pikir yang rendah untuk tingkat pendidikan.

Mengutamakan nilai ekonomi dari aspek pendidikan tanpa mengedepankan ilmu yang di dapat. Pola pikir disini masih menjadi tugas utama seluruh elemen masyarakat dalam menyadarkan pola pikir yang masih rendah dari aspek pendidikan di mata masyarakat. Selain itu, fasilitas penunjang dari lembaga pendidikan di desa tanjungsari juga menjadi pertimbangan oleh masyarakat umum dalam memberikan pendidikan bagi anak mereka. Karena di desa rajadesa sendiri dalam persaingan lembaga pendidikan (negeri ataupun swasta) menjadi pertimbangan utama minat masyarakat memilih lembaga tersebut untuk memberikan pendidikan pada anak mereka.

Dimensi yang ke empat tergolong membutuhkan nilai dari pemahaman masyarakat untuk menjaga generasi keturunan mereka. Dari sekian kasus yang di temui, problem utama yang sering terjadi dalam dimensi an-Nasl ini adalah pemahaman masyarakat petani yang masih lekat dalam tradisi menjodohkan anak mereka dengan pasangan yang sama-sama masih belum matang dan memiliki pola pikir yang belum dewasa. Sehingga kasuskasus yang terjadi pada masyarakat seperti ini adalah perceraian dan ketidakmampuan calon ibu dalam melahirkan cabang bayi sehingga beberapa dalam kasus tertentu ada calon bayi yang meninggal dan ibu yang meninggal. Kasus-kasus pada dimensi pemeliharaan keturunan menjadi sangat penting dalam melanjutkan generasi yang baik dan sehat. Dan permasalahan implementasi yang terjadi pada dimensi ke empat yaitu pemeliharaan al-Mal 
dari setiap indikator adalah peningkatan teknologi yang lebih efektif dan efisien pada teknologi pertanian.

Selain itu dalam menjaga pemeliharaan harta sebagai bentuk dari pemenuhan kebutuhan primer, sekunder dan tersier. Pada salah satu indikator dimensi al-Mal juga memiliki aspek pertumbuhan yang berarti bukan hanya kepemilikan, dalam dimensi al-Mal ini juga menekankan pertumbuhan harta kekayaan yang mana secara tidak langsung masyarakat dapat mengembangkan harta yang dimiliki sehingga akan nantinya dapat memberikan manfaat yang baik untuk pendistribusian harta kepada masyarakat yang lebih membutuhkan.

\section{KESIMPULAN}

Berdasarkan hasil penelitian, maka dapat di tarik kesimpulan sebagai berikut:

1. Implementasi Maqasid As-Syari'ah masyarakat petani di desa tanjungsari menjadi tolak ukur dalam pemenuhan dari tujuan syariat islam di sekitar lingkungan yang memiliki tujuan untuk memelihara setiap dimensi kehidupan yang ada syariah seperti menjaga agama (hifdzu ad-din), menjaga jiwa (hifdzu an-nafs), menjaga akal (hifdzu al-'Aql), menjaga keturunan (hifdzu an-Nasl) dan menjaga harta (hifdzu al-Mal). dari kelima dimensi tersebut dimaksud untuk mencapai nilai kesejahteraan dan kemaslahatan masyarakat petani desa tanjungsari di dunia dan akhirat, yaitu dengan menaati dan melaksanakan perintah yang sesuai dengan Al-Quran dan Hadits serta menjauhi setiap larangan dan kemafsadatan yang akan menimbulkan dampak yang buruk bagi masyarakat, lingkungan dan makhluk hidup lain di lingkungan sekitarnya.

2. Setiap permasalahan pada indikator dalam setiap dimensi adalah disebabkan karena kurangnya kepedulian masyarakat, ulama, pemerintah, dan tokoh setempat dalam menjabarkan serta mensosialisasikan kepada masyarakat petani terkhusus desa tanjungsari kecamatan rajadesa dalam mengembangkan sumber daya manusia untuk menjadi lebih baik dan tentu aspek yang dituju adalah kebahagiaan serta kesejahteraan di dunia dan di akhirat. Selain itu nilai yang terkandung juga akan melatih masyarakat untuk menggali potensi diri dari sumber daya manusia sebagaimana peran manusia di muka bumi adalah untuk menjaga, merawat dan mengelola segala karunia Allah SWT dengan baik-baiknya dan untuk kemaslahatan bersama. 


\section{DAFTAR PUSTAKA}

Al-Qardhawi, Y. 2007. Fiqh Maqashid al Syari'ah. Jakarta: Pustaka AlKautsar.

Anto, M. H. 2009. Introduce an Islamic HUman Development Index (I-HDI) to Measure Develompent in OIC Countries. Islamic Economic Studies.

Arikunto, S. 2010. Prosedur Penelitian: suatu Pendekatan Praktik. Jakarta: Rhineka Cipta .

Arsyianti, I. S. 2016. Ekonomi pembangunan Syariah. Jakarta: Rajawali Pers. Bachri, B. S. 2010. Meyakinkan Validitas Data Melaui Triangulasi Pada Penelitian Kualitatif. Jurnal Teknologi Pendidikan Vol 10 No. 10, 55. Bahsoan, A. 2011. Maslahah Sebagai Maqashid al-Syariah. INOVASI, 113.

Beik, I. S. 2016. Islamisasi Ekonomi. Islamiceconomic, 69-95.

Borhan, J. T. 2008. Pemikiran Pembangunan Ekonomi Berteraskan Islam. Jurnal Usuludin - University of Malaya,

Syamsuri. 2016. Paradigma Pembangunan Ekonomi; satu analisis tinjauan ulang dari perspektif Ekonomi Islam. Islamiceconomic, 219-242.

Syarwani. 2011. 40 Hadits Shahih, Ternyata Penduduk Surga Bercocok Tanam. Bantul, Yogyakarta: Pustaka Pesantren.

Tohari, C. 2017. Pembaharuan Konsep Maqashid Shariah dalam Pemikiran Muhammad Tahir Ibn 'Ashur. Al Maslahah.

Waluyo, A. 2018. Ekonomi Islam dalam Bingkai Maqashid Asy-Syariah. Yogyakarta: Ekuilibria.

Wibowo, A. 2004. Maqoshid Asy Syariah: The Ultimate Objective of Syariah. Islamic Finance.

Yusoff, A. S. 2003. Konsep, Teori, dimensi dan isu pembangunan. Malaysia: Muapakat Jaya Percitakan. 
$120\}\{$ Implementasi Maqashid Syariah pada Petani Desa Tanjungsari 